\title{
The Meeting of Myths and Realities: The "Homecoming” of Second-Generation Exiles in Post-Apartheid South Africa
}

\author{
Zosa Olenka De Sas Kropiwnicki
}

\begin{abstract}
This article is based on the findings of a qualitative study of second-generation exiles, who were born in exile and/ or spent their formative years in exile during apartheid. It is based on in-depth interviews with forty-seven men and women who spent their childhoods in North America, Western Europe, Eastern Europe, West Africa, East Africa, and southern Africa as second-generation exiles during apartheid. This article will focus on the tensions that arose over the myths and realities of return, in what often became dashed expectations of returning to a welcoming, free, and progressive post-apartheid South Africa, politically and socially united around key liberation principles. It will also discuss the manner in which the experience and memory of exile influenced former second-generation exiles' perceptions of their roles as agents of change in postapartheid South Africa-roles that were often adopted in the name of an ongoing liberation struggle.
\end{abstract}

\section{Résumé}

Cet article présente les résultats d'une étude qualitative d'exilés de seconde génération qui sont nés et/ou ont passé leur jeunesse en exil pendant l'apartheid sud-africaine. Cette étude repose sur des entrevues approfondies menées avec quarante-sept hommes et femmes qui ont grandi en Amérique du Nord, en Europe de l'Ouest et de l'Est, et dans l'ouest, l'est et le sud de l'Afrique, en tant qu'exilés de l'apartheid. Cet article examine plus précisément les tensions issues des mythes et des réalités du retour au pays, et des attentes déçues d'un retour à une Afrique du Sud accueillante, libre, progressiste et unie politiquement et socialement par des valeurs liées à l'idéal de liberté. On $y$ analyse également comment les expériences et les souvenirs de ces anciens exilés marquent leur propre perception de leur contribution à la société post-apartheid, bien souvent pensée comme une contribution à la poursuite d'une lutte pour la liberté.

\section{Introduction}

E xile in this article has been defined as a "condition" or "process" that is both historically and contextually specific, associated with forced separation, physical "banishment," and geographical dislocation compelled by a political regime. ${ }^{2}$ In the South African context, exile has been associated with a strategic space characterized by transnational political struggles against "norms of a nation."3 It is estimated that from the early 1960s, 40,000 to 60,000 South Africans were exiled, and that between 1990 and 1995 approximately 15,000 to 17,000 former exiles returned to South Africa. ${ }^{4}$ In the secondary literature, exile and return has been described narrowly as an adult experience with emphasis on the perceptions and memories of adults who waged political struggles against the apartheid state. In light of this dearth in information, this article will discuss the unique experiences of children and youth who returned to post-apartheid South Africa.

On the basis of forty-seven life-history interviews with second-generation exiles who were born and/or spent their formative years in exile, it will be argued that although 
many children had little or no lived experience or memories of South Africa, "myths of homecoming" were constructed under the influence of their parents' narrated memories and hopes of a "new" South Africa, their personal relationships with political stalwarts in exile, the international media's portrayal of political developments within South Africa, and dominant political discourses at the time. These myths were constructed around images of joyous interpersonal reunions, the realization of liberation principles, and the meaningful democratization of political processes. These myths in turn heightened expectations of homecoming. Notwithstanding the legal-policy and service-provision measures in place for voluntary returnees (and their children), disillusionment was fuelled by the reality of unbridgeable schisms in familial relationships and broader socio-political networks; inequitable racial, socio-economic, gendered, and gerontocratic hierarchies; and "false promises" pertaining to recognition, compensation, and democratic governance.

Despite these dashed expectations, it will be argued that disappointment has not fuelled passivity among the second-generation exiles in my study, many of whom have embraced agentic roles in their communities, precisely because of the manner in which their childhoods were constructed in exile, with emphasis placed on obligations and responsibilities towards their parents, the liberation movement, and the nation. The politicization of their childhoods has shaped the way that they view the post-apartheid present and future. Hence, despite the rupture brought about by the exile experience, continuity is evident in their sense of self, aspirations, and perceptions of "home." The time when notions of "home" were formed in the life cycle should, therefore, be considered when analyzing the experience of exile and return for children and youth.

\section{Conceptualizing Homecoming}

Said referred to the "perilous territory of not-belonging"5 occupied by the exile caused by the "rupture of the true self and its true home." 6 In this territory, notions of home are laden with a sense of love and loss for "one's native place"7 and for the "space where affections centre," a space from which exiles have been forcibly separated. These affections support the idealization of the "homeland" and "myths of return." "Home" in these myths is often centred on location, space, and geography, ${ }^{10}$ but may be linked to habitual notions, traditions, and cultural practices, ${ }^{11}$ even when exile locations are perpetually shifting. ${ }^{12}$ A shared history, relationships, and networks may also constitute notions of home in transnational exile communities. ${ }^{13}$ Importantly for this study, home may be linked to visions of a "triumphant ideology or a restored people."14 In recollection and narration, the past may be constructed in a way that serves the needs of the present, thereby enabling exiles to find content for notions of "home" and "belonging," often under the sway of dominant discourses and collective memorialization efforts. ${ }^{15}$ "Home" can therefore be "made, re-made, imagined, remembered or desired." 16 These constructions may relieve the pain of separation from a homeland but also keep the "myth of return" alive. ${ }^{17}$

To conceptualize return for the exile, it is necessary to disengage notions of "homecoming" from a simplistic association with location, space, and geography. Exiles do not merely return to a geopolitical concept of "country of origin"; they also return to imagined notions of home centred on remembered attachments and associations. ${ }^{18}$ Dichotomies that associate "return" with the security, stability, and belonging of fixed geographical space ${ }^{19}$ fail to consider the rupture caused not only by the initial physical separation from a "home" forced by a state or legal regime, but also the dislocation caused by separation from the state of exile in the name of "homecoming." ${ }^{20}$ Black and Gent argue that "in practice, the experience of return may be more, rather than less, problematic than the experience of exile." ${ }^{21}$

This dislocation is felt not only geographically but also in socio-economic, psycho-social, and ideological terms. In the process of "homecoming," "the nostalgia for a politics of place is challenged."22 It is therefore essential to understand the meaning of return for exiles relative to myths of return. ${ }^{23}$ These myths centre not only on the likelihood of return, but also on the timing and context to which an exile will return. ${ }^{24}$ This can create unrealistic expectations for returning exiles, which are difficult to fulfil in the country of origin. ${ }^{25}$

Parker ${ }^{26}$ and Warner ${ }^{27}$ note that returning to their country of origin does not necessarily mean going "home," because exiles may have found other "homes," fulfilled their aspirations elsewhere, and may not necessarily be able to pursue these aspirations in post-independence Africa. Not only has the individual's life and identity evolved in exile, but the state and communities in the country of origin have changed as well. ${ }^{28}$ The influence of time should, therefore, be considered in the rupture that may be experienced by returning exiles, and the process of adaptation and integration, into what may have previously existed or have been remembered as home. ${ }^{29}$ The past and future are important sources of reference in the present. Muggeridge and Dona describe the first visit home as a "meeting between imagination and reality" 30 in which returning exiles are forced to confront their perceptions of home and "transition from belief to hope, from mythologizing the past to coming to terms with the present." ${ }^{1}$ This article focuses largely on this first meeting.

It is also important to consider the life cycle and the time when "home" was defined and mythologies formed. ${ }^{32}$ Cornish and colleagues note that "returning to a homeland 
can be as stressful as fleeing into exile. This may be especially true for second-generation refugees born in exile, who are likely to find 'home' a strange or even threatening place." 33 They are bearers of "postmemory" 34 in that they have formed idealized impressions of "home" through their identification with their parents. Many cope with these dashed expectations by identifying themselves with other returnees, contributing to their isolation from local communities. 35

This study will consider the manner in which secondgeneration exiles have navigated the myths and realities of return in post-apartheid South Africa in relation to evolving legislative, political, socio-economic, and interpersonal contexts.

\section{Legal-Policy Context}

\section{Definitions}

The right to flee and seek assistance from political persecution was first articulated in Article 14(1) of the Universal Declaration of Human Rights. ${ }^{36}$ Since then, the Convention Relating to the Status of Refugees has been adopted to form the foundation of international refugee law. It defines the term refugee as "any person who has a well-founded fear of persecution because of his/her race, religion, nationality, membership in a particular social group, or political opinion; is outside of his/her country of origin; and is unable or unwilling to avail him/herself of the protection of that country, or to return there, for fear of persecution." ${ }^{37}$ South Africans in exile, by virtue of their having fled the apartheid regime, clearly met the definition of a refugee under both refugee conventions. $3^{8}$

The Organization of African Unity's Convention Governing the Specific Aspects of Refugee Problems in Africa (1969) adapted the definition of refugee to include groups of persons escaping civil disturbances. A refugee is defined under this convention to be "any person compelled to leave his/her country owing to external aggression, occupation, foreign domination or events seriously disturbing public order in either part or the whole of his country of origin or nationality." 39 This means that "individuals and large numbers of people"40 fleeing "civil disturbances, widespread violence and war"41 are also entitled to claim refugee status without showing proof of their individual circumstances beyond the fact that they come from a particular region. In its 1985 Resolution on the Root Causes of the African Refugee Problem, the council ministers noted that "the oppressive systems of apartheid, colonialism and racism constitute major causes for the exodus of refugees from South Africa."42 It referred to the situation or condition that these refugees found themselves in as a state of exile. ${ }^{43}$
Specific to exiled children, the General Assembly on 4 December 1986 adopted the Resolution on Measures of Assistance Provided to South African and Namibian Refugee Women and Children, which called upon all governments, intergovernmental organizations, and non-governmental organizations to assist refugee children outside South Africa and Namibia. ${ }^{44}$ No distinctions were made between refugee children, unaccompanied children in exile, and the children of political exiles in this resolution.

In the specific context of this article, the United Nations High Commissioner for Refugees (UNHCR) referred to returnees as "any South African refugee and/or political exile who return(s) voluntarily to South Africa as an unarmed citizen."45 Although it differentiated between refugees and political exiles in the title of its operational procedures, it did not distinguish between these two concepts both at a conceptual level and in terms of the level of assistance each category of persons was entitled to in the process of voluntary return. ${ }^{46} \mathrm{As}$ a result, the terms exile and refugee were often used interchangeably, or subsumed under the term returnee. The forthcoming section will, therefore, use the term returnee in line with key legal-policy frameworks employed at the time.

\section{Voluntary Return}

On 2 February 1990, the state president's speech recognized the African National Congress (ANC) as a legitimate political party with legitimate claims. ${ }^{47}$ It also announced the democratization of the state system, the normalization of political processes, and the onset of negotiations for a new constitution..$^{4}$ Thereafter, the release of South Africa's Nelson Mandela signalled the end of apartheid and changed the face of the region, allowing thousands of South African exiles to return home in safety.

Their return was facilitated by a number of legal and political initiatives. Chief amongst these, in 1991, a Memorandum of Understanding on the voluntary repatriation and reintegration of South African refugees and exiles was entered into between the government of South Africa and the UNHCR. 49 This granted blanket amnesty to returnees who had committed political offences before 8 November $1990.5^{50}$ Accordingly, all returnees, including those who had committed political offences or had left the territory in an irregular manner, were able to "peacefully return to South Africa without risk of arrest, detention, imprisonment or legal proceedings, whether civil or criminal, in respect of the political offences." 51

Further, the state undertook to co-operate with UNHCR on the funding, planning, and implementation of a repatriation operation. ${ }^{52}$ To facilitate the readmission, reception, and reintegration into South Africa of the returnees, the 
government and the UNHCR agreed upon a set of procedures published as an annexure to the memorandum.53 After indemnity was granted by the South African Department of Justice upon receipt of documentation from UNHCR, travel documents were to be issued by the South African authorities and delivered to the UNHCR for transmission to those who were cleared for return. 54 Of primary importance was the principle that returnees participating in repatriation were acting voluntarily, and participants signed a declaration to show that their request to repatriate was made of their own free will. 55

In the name of preserving "family unity," spouses and children of returnees who were themselves citizens of other countries were "permitted to enter and remain in South Africa on the basis of Temporary Residence Permits."56 Similarly, surviving non-South African spouses and/or children of South African citizens who may have died while abroad were granted the right to enter and remain in South Africa to preserve their family links with the territory. 57 Mechanisms for tracing family members and for family reunification were also established..$^{8}$

In the case of returnees who were unaccompanied minors under eighteen years of age, the South African authorities undertook to notify parents, next of kin, or guardians of their return, well in advance. They were "encouraged" to take immediate custody of these children or alternative placements would be found, 59 without prejudicing their readmission into South Africa. Commitments were made to provide humanitarian material assistance to support the returnee child, following an assessment of household conditions. ${ }^{60}$ The UNHCR granted transportation, immediate assistance of a grant for food, basic domestic utensils and temporary shelter for each family and/or a one-time cash grant to cover essential needs. ${ }^{61}$ This voluntary repatriation programme was praised as successful by the United Nations Human Rights Commission, which in 1993 noted with satisfaction the progress made. ${ }^{62}$

In addition, many thousands of exiles chose to return on their own, without participating in the repatriation programme. ${ }^{63}$ The General Assembly, for its part, appealed to the international community to "increase humanitarian and legal assistance to the victims of apartheid, to the returning refugees." 64

\section{Reintegration}

In order to support the reintegration of returning children from exile, legal-policy and service provisions were made for their documentation, indemnity, reparations, rehabilitation, vocational training, and education.

Since the abolition of apartheid, a number of laws have been passed that have had a significant effect on the recognition of the nationality of children born or raised in exile, upon their return to South Africa. The Restoration and Extension of South Africa Citizenship Act No. 196 of 1993 restored South African citizenship to all persons, who, but for the effect of apartheid legislation aimed at their denationalization, would have been a South African citizen by birth, ${ }^{65}$ descent, ${ }^{66}$ or naturalization, ${ }^{67}$ and who would not have otherwise lost their citizenship in terms of the ordinary application of the provisions of the South African Citizenship Act 44 of 1949 (hereafter the "1949 Citizenship Act"). Persons who had previously been disenfranchised were now able to pass on South African nationality to the children born to them either within the country or abroad (such as children born in exile). All laws aimed at the denationalization of non-white South Africans were repealed. ${ }^{68}$ Two years later, the South African Citizenship Act 88 of 1995 (hereafter the "1995 Citizenship Act") was adopted to repeal and replace the 1949 Citizenship Act. This act has since governed the acquisition and loss of South African citizenship (it remains in force today, albeit in an amended form). However, for children born before 1995, only the 1949 Citizenship Act is relevant to the determination of their nationality. Nevertheless, under the provisions of the 1995 Citizenship Act, a person who was recognized as a citizen under the old act is protected and would thus remain a South African citizen.

Many children who had been raised during the apartheid era, even those who were raised primarily or exclusively in exile, bore witness to atrocities during that time or were involved in criminal activities as members of the struggle movement. Legislation aimed at facilitating their reintegration through indemnity, reparations, and rehabilitation were outlined in the Promotion of National Unity and Reconciliation Act 34 of 1995 and the Indemnity Act 35 of 1990.

In terms of education, under the Memorandum of Understanding, diplomas, certificates, or degrees acquired by returning exiles while abroad were considered as valid by the competent authorities. To facilitate the integration of any unskilled returnees-notably the youth-into the economy, provisions were made for on-the-job training and apprenticeships. ${ }^{69}$

It was noted that "children of the returnees were affected by the failure to guarantee schooling." 70 This led to the establishment of the Batlagae Trust in 1991 by the Oversight Committee of the National Coordinating Committee for the Repatriation of South African Exiles (NCCR) in collaboration with the liberation movements and the South Africa Council of Churches to assist the educational reintegration of political exiles, under the executive directorship of Mohammed Tikly. ${ }^{71}$ Approximately $\mathrm{R}_{30}$ million was 
received by the trust between 1992 and 1995, largely from the Nordic states and a few external non-governmental organizations and South African donors. Its mandate included administering a bursary program for returnee scholars at all levels of study and the establishment of a reception centre with educational facilities for repatriated parents who could not be reunited with their families. ${ }^{72}$

In terms of the former, approximately 10,00o learners ranging from nursery to postgraduate level received bursaries for fees and books between 1992 and 1996. In terms of the latter, the Yeoville Community School was established to provide nursery and primary schooling to approximately 200 returning children between 1993 and 1995, with financial assistance from the provincial Department of Education. In addition, the Yeoville Educational Polyclinic provided psychological and academic support to returning children from preschool to high school levels in Johannesburg between 1993 and 2000.73

The Batlagae Trust also included representatives from Sacred Heart College who assessed children at Solomon Mahlangu Freedom College and expedited their repatriation and placement. Sacred Heart College raised funds independently to accommodate these children, with assistance from the Anglo-American Chairman's Fund. ${ }^{74}$ Records from the 487th Meeting of the Executive Committee of the Programme of the United Nations High Commissioner for Refugees on 7 October 1993 noted that the trust was short of R8.5 million to assist approximately 2,600 beneficiaries in $1994 . .^{75}$ However, there is little documented information available about the reach and impact of the trust in terms of second-generation exiles' well-being.

The Umkhonto we Sizwe Military Veterans Association Trust also provided scholarships to returning exiles. Apart from media articles on the misuse of R5.4 million of these trust funds by $\mathrm{MK}$ Veteran leaders, ${ }^{76}$ no information is available on the scope, reach, and impact of these trusts on children.

\section{Literature Review}

Various studies have considered the material and psychosocial challenges experienced by returning exiles. Reference has been made to a shortage of accommodation and employment, 77 leading to dependency on the African National Congress (ANC) settlement and chronic-illness medical aid allowances, as well as the cash grants. ${ }^{78}$ It also led to long-term dependency on relatives for accommodation and subsistence, thereby souring interpersonal relations. ${ }^{79}$ Many experienced a range of psycho-social challenges including post-traumatic stress syndrome, ${ }^{80}$ "reverse culture shock," altered living conditions, dislocated social networks, unrealistic family expectations, loss of a defined collective, political identity, and realization that notions of "home" were merely "idealized" constructions. ${ }^{81}$

Despite the plethora of research on adult returnees, the experiences of children have been neglected. Sixteen per cent of Majondina's sample was born in exile, but the significance of this was not discussed. ${ }^{82}$ His survey also included questions related to children's adjustment in South Africa, of which 34 per cent mentioned little or no difficulty in return and 66 per cent mentioned some to extreme difficulty. However, the nature of these difficulties and children's coping strategies were not discussed. Nine per cent of Cock's sample included people aged sixteen to twenty years; however, the findings were not disaggregated by age. She also referred to children who were left behind when their parents joined Umkhonto we Sizwe in exile and quantified the number of dependents per cadre, but she failed to discuss the particular challenges faced by these dependents as second-generation exiles or children who were "left behind." ${ }^{3}$ Nell and Shapiro referred to exiles' "difficulty in taking on social roles such as mother, father or breadwinner." 4 However, they failed to highlight what it meant to be a child cared for by these troubled former combatants.

In other secondary sources, passing reference has been made to linguistic challenges hindering children's transition into school. ${ }^{85}$ Lissoni stated in passing that children from former exile families were forced to leave school or join their fathers at the South African Defence Force as the result of poverty. ${ }^{86}$ Manghezi described the challenges faced by an unrepresentative sample of four children of political leaders in returning to South Africa. ${ }^{87}$ Ngcobo's collection of life stories also highlighted some of the challenges faced by second-generation exile children whom she described as "mutated," 88 because they have "intrinsic or inbuilt recollection or memory card of the 'home' that others make frequent references to." ${ }^{9} 9$ These exile children were shocked by "rejection," "unending joblessness," and the loss of "freethinking attitudes, public analysis and debate" upon return to post-apartheid South Africa. $9^{\circ}$ She also argued that their exposure to "a different reality and set of values early on in their lives-such as non-racial human and social interactions"91 could prove to be an asset in post-apartheid South Africa. However, the extent to which the children of returning exiles can play a role in South Africa's political, social, cultural, and economic development has not been explored. Many of the second-generation exiles are now youth, who can potentially become key "agents of change"92 in postapartheid South Africa.

\section{Methodology}

This study sought to understand the manner in which childhood was constructed and experienced in exile during 
apartheid and upon return to South Africa. This article focuses on the latter. Secondary and primary data were collected for this study. Secondary data included accredited journal articles, academic books, autobiographies, and biographies. A detailed review of media articles and legalpolicy documents was also undertaken.

Primary data were collected from July 2013 to August 2014 in Gauteng, Western Cape, and Kwa-Zulu Natal Provinces. Forty-seven second-generation exiles who were born and/or spent their formative years (to the age of eighteen) in exile during apartheid and who had returned to South Africa were identified through snowballing. Non-directive questions were posed to respondents in relatively unstructured interviews, using a life history approach. The interviews were digitally recorded, transcribed, and shared with respondents to verify the data or raise concerns, although no such concerns were raised. Open coding was used to categorize and examine themes and patterns using Microsoft Word.

The ethical standards promoted by the Oral History Association of South Africa Code of Conduct guided the study. 93 This included provisions for informed written consent, the right to withdraw or seal a transcript, confidentiality and anonymity, and protected storage of data. Given the potential for "pain caused by remembering difficult memories,"94 respondents were encouraged to contact qualified counsellors at the University of Johannesburg, although this opportunity was not taken up.

The main limitation of this study is the nature of retrospective interviews and the potential for memory lapses 95 as well as the "inauthenticity" of memories as a source of data, considering their construction and selective recovery. ${ }^{96}$ Nevertheless, the narration of memories provides opportunities for reflection, ${ }^{97}$ gives insight into partial perceptions and diverse versions of experiences, and may give voice to the marginalized..$^{8}$

The sample characteristics were as follows: twenty were male and twenty-seven were female. Under official South African race classifications, twenty-seven were black, nine were Indian, six were white, and five were coloured. At the time of the interviews, four were younger than thirty years of age, sixteen were aged thirty to thirty-five, ten were aged thirty-six to forty, and seventeen were older than forty-one years.

The ages at which respondents went into exile were as follows: twenty-five were born in exile; fifteen were aged one to five years, and seven were older than seven years. Ten returned to South Africa when they were aged up to ten years, fifteen were aged eleven to eighteen years, and nineteen were older than nineteen years. Two respondents have since returned to their exile communities.
When in exile, families moved frequently. In exile, fourteen lived in one country, ten lived in two countries, fifteen lived in three countries, and seven lived in four countries. With this in mind, twenty-nine spent a period of exile in southern Africa, eighteen in eastern Africa, three in West Africa, one in South East Asia, eight in Western Europe (excluding the United Kingdom), nineteen in the United Kingdom, eleven in the former Soviet Bloc, eleven in North America, and one in Australasia. These figures are significant if one considers that the return to South Africa was one move following many others, each move bearing a potential for "rift and rupture," as argued by Said. 99

\section{Findings}

\section{The Myth of Homecoming}

Home for many exiles was not necessarily related to geographical space, traditions, or attachments, but was associated with a "triumphant ideology or a restored people."100 This ideology centred on beliefs of a liberated South Africa: "There was a whole language about when we go back, when we are free, and when Mandela is free. So it was definitely part of my psyche growing up, that it [exile] was a temporary situation."101 In exile, "home" was constructed as a transitory sojourn, on a voyage leading back to South Africa.

As many were born in exile and/or spent their formative years in exile, children found themselves "parroting" their parents' "longing for home and their perception of home." 102 This longing was often based on memories of a mythic past, with its static attachments and associations: "They [my parents] didn't prepare me much, because they were thinking they were going back to fourteen years earlier, so they weren't that prepared either."103

Elsewhere I have discussed the political socialization of second-generation exiles. ${ }^{104}$ At various stages in their life cycles, mythologies of "home" crystalized under the influence of narratives that emerged before they were born. ${ }^{105}$ This informed their constructions of homecoming: "I guess growing up outside of South Africa for most of their [parents] lives, they saw post-apartheid South Africa through rose-coloured glasses and that is how we were always brought up."106

For most exile families, the release of Nelson Mandela was a turning point in the decision to return home. Exile communities eagerly watched television broadcasts of this event, which contributed to excited anticipation of return to the "beautiful place that South Africa will become."107 In this period, the myths of "home" solidified. As a respondent noted, "There was a sense of things having changed, like a 'freedom will reign supreme' kind of atmosphere. So it was a very hopeful time. We believed that home was paradise, 
but when we got to South Africa, we got the shock of our lives." 108

Some recalled having little decision-making power over the decision to return, in part because they were young: "I was just a kid, following everyone around. I wasn't given much of a choice."109 Others actively wanted to return despite the risks: "We didn't know what it was like to go back home as exiles: my parents were not sure what would happen and if my dad would get arrested. I didn't want to wait, I wanted to go back home. It is ironic that I am calling it home, even though I had never been there."110

Children did not passively accept this mythology of "home" but actively interpreted and resisted it. One respondent contacted a Danish social worker seeking out alternative familial placements to avoid returning to South Africa. She described the devastation that she experienced in leaving significant social networks in exile. This desolation often played out in the "non-spaces"111 of transit lounges, motels, and airplanes-spaces that are in fact laden with meaning. For instance, some respondents recalled experiencing motion sickness that originated less from the flight and more from "feeling sad and lonely," 112 while others remembered feeling disconnected from the excitement and anticipation felt by their families: "My sister and my dad didn't have a problem coming out here. They were just eating toasted sandwiches while I was crying and crying. I just felt so hopeless. I felt stripped of grounding and identity."113

\section{Interpersonal Myths and Realities}

The first visit home was indeed a "meeting between imagination and reality."114 For children of ANC leaders, memories of arrival centred on security and public accolades: "The airplane came into the airport and it was surrounded by this perfect circle of South African police wearing dark glasses. It was extraordinary ... We were put on a platform overlooking all these people. Standing up there and seeing this ocean of people, it was like 'Wow, Daddy, is this all for you?"'115

In contrast, many other children were confronted with the harsh reality of empty airport arrival halls that did not coincide with their expectations of return: "It was such a long flight, and when we were arriving the sun was just rising, and it sort of burst red, and it felt like a new beginning, but a heavy new beginning. They [relatives] didn't even come and meet us at the airport, and that let us know that we were coming into a battle; we weren't coming home to a sea of kisses and hugs and love."116

In some cases, meaningful interpersonal encounters were thwarted by the absence of shared histories: "You look like these people, but you have nothing in common. We don't have a history." 117 This was particularly salient for reunions involving siblings who were left behind. In addition to material hardships and racial prejudice, they experienced a sense of parental abandonment. Anger and guilt characterized these first unions: "They blamed me because I was given the love that should have been shared amongst all of us."118

Initially, many returning exile children were treated like "celebrities,"119 but this response was quickly replaced by accusations that they had absconded from their "frontline" duties in the liberation struggle. Many spoke of an unexpectedly hostile reception from relatives and the disappointment that they felt when the "romantic view of being welcomed"120 failed to materialize: "Certain uncles and aunts ignored me, and there you are, arriving back, expecting open arms, because you have been fighting the struggle your entire life in exile."121

While they were in exile, their relatives suffered under an oppressive regime. Reunions were often marred by blame and guilt: "They said that we had a better life, we were lazy and at fault for not being here." 122 Assumptions were made that exiles lived lifestyles of "champagne and money," without acknowledging the everyday struggles facing many second-generation exiles, including poverty, violence, and social exclusion: 'I suffered, maybe not in the context of being shot at by rubber bullets, but there were times when there was no food. There were times you worried about your safety. There were times when you got bullied. There were times when I felt unloved and rejected, not by my family but by the world, like no one gave a damn." 123

In place of experiencing compassion, many secondgeneration exiles were jeered, taunted, and socially excluded in the playground. "Instead of being 'Wow, your father died for us,' it was more like, 'Who do you think you are? You weren't even here."'124 This was a shock for many children who believed that their sacrifices would be acknowledged upon return: "We were taught that we would be heroes, and all the stuff we were giving up was for this greater good, and it would be appreciated one day, and it never was." 125

Language constraints hindered communication with relatives and peers. Respondents were called "traitors" for speaking English. ${ }^{126}$ Many parents dedicated their time to the struggle, often at the expense of their children's linguistic development: "My mother didn't get a chance to teach me her language. She would have if she could, but you people were more important than we were. So just be grateful to them for what they did for this country. You have no right to judge us. Our parents sacrificed everything for this country, including me."127

Some respondents struggled to identify with cultural practices. The sudden pressure to participate in initiation ceremonies upon return fuelled frustrated exchanges 
between exile children and their parents: "You start asking your parents, 'Why didn't you do this for me when I was a child?' and they say, 'Well, we don't do that in our other [American] culture."'128 Another respondent spoke of being forced to undergo training as a traditional healer, despite her Western upbringing. ${ }^{129}$ Some were chastised for behaving in a "snobby way" 130 because they found it difficult to eat unfamiliar foods or wear traditional dress. They were harried to adapt to the culture as soon as possible, often fuelling intergenerational tension.

Suddenly children were treated differently by their parents, many of whom were described as very 'liberal' in exile but upon return paid credence to traditional constructions of childhood: "Before, I could drink with my parents and tell them about my boyfriends. But in South Africa everything is now a secret and parents choose to believe their teenagers are innocent five-year-olds." ${ }^{131}$ Many were disciplined for "talking back to the elders" 132 when engaging in what they regarded as commonplace communication and enquiry. Suddenly they had to deal with the scrutiny of a large family, which they were not used to in the relative isolation of exile.

The majority of respondents described integration into such social networks as a source of stress and disappointment: "I think central to being an exile child is that we go back to the places and communities that our parents left, as strangers. Our families, communities, and countries do not accept us."133 As a result, many children sought out their own exile communities within South Africa. Referring to Sacred Heart School, one respondent stated, "I would gravitate to other exile kids. It felt like a different world. It was like an island. We only felt different when we left the school, like when I used to visit my cousins in the township. They called me names."134

\section{Liberation Myths and Realities}

For returning children, disappointment often centred on interpersonal struggles. For others, it was related to the uneasy meeting of myths and realities associated with liberation: "I thought to myself that we were going to come back to black, green, and gold flags flying, but it wasn't what happened. We thought the ANC comrades would be like the ones we had grown up with, so it would be a nice safe place, but I came back to a completely racist, angry space where everyone is nuts." 135 While many South Africans are critical of political and socio-economic developments, the critique voiced by second-generation exiles stems from their unique experiences in exile, the myths of return constructed in exile, and the meeting of myths and realities upon "homecoming."
Many believed that they would be returning to a liberated, free, and equal society in which racial, socio-economic, gender, and generational hierarchies would be dismantled through the struggle. However, the reality was very different, particularly in the schools and playgrounds to which they returned. Reference was made to racial discrimination from peers and teachers alike, which was particularly salient for children who had attended interracial schools, embraced cosmopolitanism, and questioned racial hierarchies in exile. White children were offended that their former black friends from exile would not play with them for fear of being ostracized by the black community; excuses included "people are going to think that I am sucking up to white people." 136 The manner in which South Africans categorize people in racial terms contradicted their construction and experiences of childhood: "People are forcing this whiteness on me. It means that when I walk into a shop, I don't get followed around in case I am going to steal, like all my black friends do. I counted myself as part of everyone else in exile, but all they care about here was that I am white."137

Black respondents complained that their white peers at school would exclude them, and use discriminatory language and violence: “They would say, 'Shut up kaffir,' hold me down, and beat me to a pulp." 138 Teachers openly humiliated black children in front of their peers, such as by punishing them for their "exotic" hairstyles and "tribal ways."139 Being forced to wear a school uniform and learn Afrikaans-"the language of the oppressor"140_-was a source of discontent shared by the majority of returning exile children.

Returning children were also concerned about levels of xenophobia in their schools, particularly since many exile families were welcomed by the same African nations that are under attack by South Africans: "Xenophobia is such a big thing, for me who has been living outside of this country and has been so warmly welcomed by all types of African people. It almost feels like a betrayal for me not to stand up for them, because they stood up for me. ${ }^{141}$ "

Overlapping socio-economic and racial hierarchies in South Africa were particularly salient for these returning children. Upon return, many white second-generation exiles were separated in geopolitical and socio-economic terms from children with whom they had grown up in exile. When confronted with the reality of their peers living in far-off townships, "It was like, 'Oh, this is what apartheid is.' Just because the ANC was unbanned, doesn't mean apartheid was dismantled." 142

Many black respondents who lived in North America and Western Europe provided vivid descriptions of the change in landscapes and spaces as they moved into the townships upon arrival in South Africa. The physicality of space and the sensory experience emerged as central in 
their narrated memories. ${ }^{143}$ For instance, "After we left the airport, we were driving into the township and I remember asking Mom, 'Why is it so dark here? Why are there no street lights? Why are people living in cottages squashed together?' Immediately when we arrived, we sensed that something was not right." 144 These sensory descriptions underscore the magnitude of the socio-economic and geopolitical changes to which second-generation exiles would have to become accustomed.

Others had a different experience, particularly when they had moved from front-line states to South African middleclass suburbs. Their descriptions were equally vivid: "I remember when we got to this apartment, the gate opened by itself and I was like, 'Oh my goodness, look at this gate. We are living the life right now. This is the land of milk and honey!"'145 The children of political leaders often referred to the sudden change in their landscapes, now comprising swimming pools, spacious gardens, and often tennis courts. Hence, during their first visit "home," second-generation exiles experienced first-hand the effect of socio-economic hierarchies, which they were brought up to believe would be dismantled in the 'liberated' South Africa. Time has done little to change this reality.

Despite being brought up to believe in a society of gender equality, many girls suddenly experienced pressure to marry and adopt subservient roles. They were unexpectedly confronted with images of their mothers "on the floor serving men," 146 and they felt pressed to conform to these traditional constructions of gender: "There is no way to contest that very easily, because the structures are so rigid."147 Victims of sexual and gender-based violence denounced the failure of their parents and the ANC leadership to bring perpetrators of sexual violence to justice upon return: “That messed me up ... In South Africa it has been normalized by society." 148 In this regard, reference was made to the recent trial of Jacob Zuma, who, it was alleged, had raped a former second-generation exile. ${ }^{149}$

Gendered restrictions on freedom of movement were justified on the grounds of safety and security from violence, which many respondents argued was "not endemic in the places we grew up." 150 The narrated memories were littered with visual descriptions of the physical effect of interpersonal violence on the landscape of post-apartheid South Africa, and in turn on the construction and experience of childhood: "Our parents brought us up as highly independent, but then you come here. You can't even look out the window without these burglar bars. It was a prison. Everyone was like, 'Oh, my God, you can't walk about by yourself as a girl."' 151

Respondents argued that this violence is symptomatic of a "damaged society": "Right now we are all pretending that only the kids who went into the army are damaged-rubbish." 152 Through comparisons to the exile communities in which they had grown up, reference was made to the perpetuation of a "culture of violence" in post-apartheid South Africa: "We are a violent nation. We resolve things with violence and ironically the countries that I have lived in [in exile] don't."'153

\section{Political Myths and Realities}

Upon return, many second-generation exiles were confronted with a stark contrast between the political myths of a progressive and politically united country and the realities of false promises, party-political divisions, corruption, and government inefficiency. This has become particularly salient over time: "I look back and I see how naïve my parents were, how naïve we all were to think that everything is going to fall into place, that we would just return to SA and everybody would just live in harmony. I feel a lot of disappointment at the direction we are taking as a country. There has been a shift from a sense of collective to entitlement."154

False promises emerged as a recurrent theme in the study. While some respondents argued that exile children are no more deserving of support than those who had remained behind, many criticized the ANC for failing to live up to its obligation to returning exiles. It was argued that more should have been done to provide psycho-social assistance to second-generation exiles, who were experiencing exile yet again, ironically in their "homes" of origin: "Absolutely nothing was done for the children who went into exile. And for a lot of them, they went into exile when they came back. A lot of them are suicidal and have drinking problems. Something has to be acknowledged."155

Reference was also made to the maladministration and inequitable distribution of funds earmarked for secondgeneration exiles: "There was a situation where children of top ANC ranked members were going to good schools and those lower down were not able to access those funds." 156 The sudden suspension of a respondent's scholarship from an MK Trust Fund was attributed to corruption. Secondgeneration exiles are still approaching SOMAFCO for financial assistance: "It pains us, what we read about the history of SOMAFCO. It is supposed to be shared amongst us, the people of South Africa so we cannot be an exclusive group, but they [second-generation exiles] need assistance."157 Respondents spoke of the failure of the ANC to compensate their parents for their work in exile, leaving them unemployed or eking out a meagre living in the informal economy.

Many argued that the ANC no longer represents the principles of the liberation struggle and angrily described the corruption of the ANC leadership. Political leaders were often known personally by children in exile. Their presence 
in the narratives underlines the sense of disappointment that second-generation exiles felt about the failure of the myths of liberation and return to materialize: "I feel that generation let us down. They were supposed to be leaders. You can imagine there is a scandal involving Mac Maharaj; this is the person who taught me the Freedom Charter. You don't know who to believe. People who you looked up to as heroes are being exposed as 'tenderpreneurs' and you don't know who is lying. I look at the ANC now and I don't know what can save it." 158 Others felt taunted by the images of previously beloved political leaders, who failed to address corruption and poor service-delivery: "There is this picture of Zuma, the man I grew up with, who gave me my first pol itical lesson when I was small. There is this picture of him smiling over us, with these people treating us like animals. I remember phoning my mother and saying, 'Is this what my father died for?'"159

For many exile families this was a source of pain. "Homecoming" has revealed that their beliefs in the ANC and its leaders were to a large extent beliefs in myths: "We were so disillusioned. We were brought up with struggle music, but now it is too painful to listen to it. My mom made my father promise from now on, this chapter would be dedicated to us as a family and no longer to politics." 160 Even more startling is the extent to which the liberation principles that featured so prominently in the way that their childhoods were constructed have been shaken: "People turned their backs on those ideals as they turned to getting their lives in order, making money and getting top jobs. It felt like a betrayal." 161

Although many second-generation exiles do not experience any sense of obligation towards the ANC, they described the responsibility that they feel towards their parents and those who died in the struggle. Beyond these interpersonal duties, many spoke of a deeper sense of responsibility to "take the legacy forward" 162 by continuing to live the struggle in post-apartheid South Africa: "We grew up with a vision for utopia for South Africa and we were allowed to experience some of that utopia in our childhood, but we didn't know it at the time. But now our job in the society is to create that vision for utopia from within, not from outside, but inside." 163

Many have described themselves as "agents of change" trying to hold the leadership accountable to the principles of liberation, through their work as social commentators, journalists, academics, writers, poets, and artists. Others work actively in social development, seeking to dismantle the racial, socio-economic, gendered, and generational hierarchies described in this article. This desire to bring about change has its roots in constructions of childhoods in exile: "As a fourteen-year-old, if you asked me what I lived for, I would tell you that I lived to liberate my country, nothing more. If you asked me now, I would not tell you a different story because my purpose is not over; liberation is still needed."164

\section{Concluding Reflections on Home, Time, and Space}

Said argues that for exiles, experiences in "new" environments occur "contrapuntally"165 with memories of experiences in "old" environments. This holds true for those who have returned to South Africa. Their narratives contain juxtaposed descriptions of the exile past, post-apartheid present, and the potential for a future that mirrors the "myths of home" constructed in exile.

Second-generation exiles found it particularly difficult to adapt to what they were brought up to believe would be their authentic "home." The findings suggest that the first meeting of myths and realities upon arrival in South Africa set the tone for ongoing challenges in integration. These returnees were forced to confront the truth that the myths they had grown up with-the welcoming warmth of social networks, the freedom and equality of a liberated society, and a just and fair political system-did not coincide with the reality of post-apartheid South Africa. This fuelled disappointment, frustration, and nostalgia towards the exile experience.

Although this disappointment has not dissipated over time, many have carved out new roles, identities, and social networks, which have made the experience of return easier. The role of time in mediating the return and integration experience should therefore be considered. Respondents spoke of initially being forced to "choose" a singular identity confined to geographical spaces associated with exile and the country of origin. However, over time they have forged their own identities, in part as a result of their maturation.

Many have avoided the "exile" label, given its association with the negative social stereotypes described above. Instead, they have appealed to notions of cosmopolitanism and a "plurality of vision" 166 to argue that they cannot be "boxed in by territorial labels." 67 They are "children of the world"168 and "international citizens," 169 who are at liberty to challenge social norms, criticize unjust hierarchies, forge unrestricted social attachments, and explore the multiple and intersecting dimensions of their identities. Their identities are perpetually "becoming,"170 and should be seen on a continuum of past, present, and future. Exile does not define them, but it has influenced their world view and sense of self.

"Home" for these cosmopolitan exiles is not within a particular country, and it does not necessarily entail "being acknowledged or accepted anywhere." 171 "Home" is far more personal, defined by each individual differently at different times, in relation to relative to varying interests, evolving 
spaces, and dynamic social networks. For some, "home" is associated with a shifting space "where affections centre, ${ }^{172}$ creativity thrives, ${ }^{173}$ or attachments form. For others, "home" is associated with landscapes and sensory experiences. For many second-generation exiles in this study, "home" is centred on an unwavering belief in the vision of a liberated South Africa and a sense of duty towards bringing this vision to life.. Although notions of "home" may be populated by memories and myths, many second-generation exiles earnestly believe that the liberation vision is not a utopian myth, but can materialize as reality in post-apartheid South Africa. Many former second-generation exiles have, therefore, embraced agentic roles in order to contribute to the fulfilment of this reality.

Some second-generation exiles called for financial and material compensation from the ANC-led government, in line with the demands currently voiced by second-generation exiles who returned to Namibia. ${ }^{174}$ In South Africa, an alternative could be the targeting of unemployed secondgeneration exiles in the second phase of the Youth Service program, as outlined in the National Youth Policy (2009-14) in order to develop their skills (and self-efficacy) through accredited learning, voluntary work, and eventually paid employment. ${ }^{175}$ Alternatively, they could be targeted in the Youth Work program, so that as peer counsellors and mentors, their beliefs in the liberation vision, respect for diversity, and sense of civic responsibility can become a positive influence on other youths. ${ }^{176}$ Some respondents recommended the strengthening of social networks, such as the SOMAFCO Trust, through funding, administrative support, and capacity building. Once again the provisions of the National Youth Policy could be applied to strengthen these social networks, which are described in this policy document as important for the development of youth identity, self-esteem, and belonging. ${ }^{177}$ Furthermore, these networks could be capacitated to locate other second-generation exiles, who are engaged in risky behaviour and/or are particularly marginalized and vulnerable, to promote their engagement in community service, positive forms of recreation, and socio-economic inclusion. Furthermore, the policy could be used to support the development of targeted psycho-social interventions for vulnerable and marginalized second-generation exiles, many of whom have failed to adjust to the realities of post-apartheid South Africa. ${ }^{178}$

In addition to the concrete actions described above, all of the second-generation exiles wanted some form of acknowledgment and meaningful recognition of the diversity of the exile experience, their trials and tribulations in exile and return, and their ongoing efforts to further the liberation struggle in South Africa. As 2014 marks the twenty-year anniversary of the official dissolution of apartheid, many second-generation exiles argued that this would be an opportune time to showcase their agentic action to inspire other youth to behave as agents of change. Thus far, however, the results have been disappointing. For instance, recent television broadcasts on Heritage Day (24 September 2014) perpetuated the stereotypical images of spoilt exile children living in the lap of luxury both in exile and upon return to South Africa. This article is, therefore, timely in that it tries to draw out the complexities of return as experienced by children and highlights the important roles that many second-generation exiles are playing as social commentators, activists, and development practitioners in post-apartheid South Africa.

\section{Notes}

1 James Clifford, "Diasporas," Cultural Anthropology 9, no. 3 (1994): 302-38; Avtar Brah, Cartographies of Diaspora: Contesting Identities (London: Routledge, 1996).

2 Edward W. Said, Reflections on Exile and Other Essays (Cambridge, MA: Harvard University Press, 200o), 181.

3 Clifford, "Diasporas," 307.

4 Zonke Majondina, "Dealing with Difficulties of Return to South Africa: The Role of Social Support and Coping," Journal of Refugee Studies 8, no. 2 (1995): 213.

5 Said, Reflections on Exile, 177.

6 Ibid., 173.

7 Ibid., 181.

8 Kenneth, "Home Is Where the Heart ... Lies," Transition 59 (1993): 67.

9 Anne-Marie Fortier, Migrant Belongings: Memory, Space, Identity (Oxford: Berg, 200o).

10 Avtar Brah, Cartographies of Diaspora: Contesting Identities (London: Routledge, 1996), 180; and Barbara Bender and Margot Winer, eds., Contested Landscapes: Movement, Exile and Place (Oxford: Berg, 2001).

11 Devleena Ghosh, "Coda: Eleven Stars over the Last Moments of Andalusia," in Critical Studies, Exile Cultures, Misplaced Identities, ed. Paul Allatson and Jo McCormack (Amsterdam: Rodopi, 2008), 284.

12 Brah, Cartographies of Diaspora, 180.

13 Paul Allatson and Jo McCormack, "Introduction," in Exile Cultures, Misplaced Identities, ed. P. Allatson and J. McCormack (Amsterdam: Rodopi, 2008), 20.

14 Richard Black, 'Conceptions of 'Home' and the Political Geography of Refugee Repatriation: Between Assumption and Contested Reality in Bosnia-Herzegovina," Applied Geography 22 (2002): 126.

15 Ibid., 126; and Sarah Nuttall, “Telling 'Free' Stories? Memory and Democracy in South African Autobiography since 1994," in Negotiating the Past: The Making of Memory in South Africa, ed. Sarah Nuttall and Carli Coetzee, 75-88 (Oxford: Oxford University Press, 200o).

16 Black, "Conceptions of 'Home,"” 126. 
17 Ibid.; and Daniel, "Voluntary Repatriation and the Meaning of Return to Home: A Critique of Liberal Mathematics," Journal of Refugee Studies 7, nos. 2/3 (1994): 160-74.

18 Warner, "Voluntary Repatriation," 165.

19 Richard Black and Saskia Gent, "Sustainable Return in Post-Conflict Contexts," International Migration 4, no. 3 (2006): 20.

20 Warner, "Voluntary Repatriation," 166.

21 Ibid.

22 Black and Gent, "Sustainable Return," 20.

23 Roger Zetter, "Reconceptualizing the Myth of Return: Continuity and Transition amongst the Greek-Cypriot Refugees of 1974," Journal of Refugee Studies 12, no. 1 (1999): 1-22.

24 Mark Graham and Shahram Khosravi, "Home Is Where You Make It: Repatriation and Diaspora Culture among Iranians in Sweden," Journal of Refugee Studies 10, no. 2 (1997): 115-33.

25 Black and Gent, "Sustainable Return," 15-38.

26 Parker, "Home Is Where the Heart ... Lies," 67.

27 Warner, "Voluntary Repatriation," 171.

28 Ibid., 172.

29 Ibid.; and Zetter, "Reconceptualizing the Myth of Return," 1-22.

30 Helen Muggeridge and Giorgia Dona, "Back Home? Refugees' Experiences of Their First Visit Back to Their Country of Origin," Journal of Refugee Studies 19, no. 4 (2006): 427.

31 Ibid.

32 Black, "Conceptions of 'Home," 127.

33 Flora Cornish, Karl Peltzer, and Malcom Maclauchlan, "Returning Strangers: The Children of Malawian Refugees Come 'Home'?" Journal of Refugee Studies 12, no. 3 (1996): 265.

34 Marianne Hirsch, "Past Lives: Postmemories in Exile," in Exile and Creativity: Signposts, Travellers, Outsiders, Backward Glances, ed. S.R. Suleiman (Durham, NC: Duke University Press, 1998), 420.

35 Cornish, Peltzer, and Maclauchlan, "Returning Strangers," 279.

36 Article 14(1) of Universal Declaration of Human Rights, Resolution 217 A (III) of 10 December 1948. United Nations, General Assembly. Paris.

37 United Nations, Treaty Series (189): 137. Entered into force 22 April 1954.

38 Sam Amaize Aiboni, Protection of Refugees in Africa (Uppsala: Svenska Institutet For Internationell Ratt, 1978), 32.

39 Organization of African Unity (OAU), Convention Governing the Specific Aspects of Refugee Problems in Africa ("OAU Convention"), 10 September 1969, 1001 UNTS 45, refworld, http://www.refworld.org/docid/3ae6b36o18. html.

40 Rachel Murray, Human Rights in Africa (Cape Town: Cambridge University Press, 2004), 188.
41 Kate Jastram and Marilyn Achiron, Refugee Protection: A Guide to International Refugee Law (Geneva: UNHCR and Inter-parliamentary Union, 2001), 13, http://www.ipu.org/ pdf/publications/refugee_en.pdf.

42 Council of Ministers of the Organisation of African Unity, Resolution on the Root Causes of the African Refugee Problem (CM/Res 987(XLII), Forty-Second Ordinary Session in Addis Ababa, Ethiopia. See also International Conference on the Plight of Refugees, Returnees and Displaced Persons in Southern Africa (CM/Res. 1181 (XLIX).

43 C. O. C. Amate, Inside the OAU: Pan-Africanism in Practice, New York: St. Martin's, 1986), 471.

44 United Nations General Assembly, Resolution on Measures of Assistance Provided to South African and Namibian Refugee Women and Children (GA Res 41/123) of 4 December 1986. On this topic, see also General Assembly resolutions 34/93 K of 12 December 1979, 35/206 N of 16 December 1980, and 36/172 K of 17 December 1981.

45 Memorandum of Understanding between the Government of the Republic of South Africa and the United Nations High Commissions for Refugees on the voluntary repatriation and reintegration of South African refugees, GN 2814, published in Government Gazette 13644 on 29 November 1991.

46 UNHCR, "South Africa Repatriation Operation: Information for South African Refugees and Exiles on Voluntary Repatriation," 24 October 1991.

47 Bertus De Villiers, Birth of a Constitution (Cape Town: Juta, 1994), 4.

48 Ibid.

49 Section 3(a), Memorandum of Understanding.

50 Ibid.

51 Section 3(b), Memorandum of Understanding

52 Ibid., Section 4(d), Memorandum of Understanding.

53 Annexure A, Memorandum of Understanding.

54 Section 8, Annexure A, Memorandum of Understanding.

55 UNHCR, "South Africa Repatriation Operation."

56 Section 13, Annexure A, Memorandum of Understanding.

57 Ibid.

58 Section 14, Annexure A, Memorandum of Understanding.

59 Section 19, Annexure A, Memorandum of Understanding.

60 Section 22(b), Annexure A, MemorandumofUnderstanding.

61 Section 22(c), Annexure A, Memorandum of Understanding.

62 Commission on Human Rights, Resolution 1993/9 of 24 February 1993.

63 UNHCR, "Lesotho Marks the End of an Era for Apartheid's Refugees," 26 August 2002, http://www.unhcr. org/3d6a139e4.html.

64 Resolution A/RES/48/159, Elimination of apartheid and establishment of a united, democratic and non-racial South Africa (24 January 1994) section 13.

65 Section 3, Restoration and Extension of South Africa Citizenship Act No. 196 of 1993.

66 Ibid.

67 Section 4, Restoration and Extension of South Africa Citizenship Act No. 196 of 1993. 
68 Section 5, Restoration and Extension of South Africa Citizenship Act No. 196 of 1993.

69 Article 24, Annexure A, Memorandum of Understanding.

70 James Ngculu, The Honour to Serve: Recollections of an Umkhonto Soldier (Claremont: David Philip, 2010), 206-7.

71 "Batlagae Trust Records, 1991-2002," ANC Archives, http://ancarchives.africamediaonline.com/?page_id=62.

72 Ibid.

73 Ibid.

74 Neil McGurk, "History of Sacred Heart College," unpublished, 2014.

75 Executive Committee of the Programme of the United Nations High Commissioner for Refugees, Summary Record of Forty-fourth Session, 487th Meeting, 7 October 1993, Geneva (A/AC.96/SR.487, 12 October 1993).

76 Lionel Faull, "Leading MK Vets 'Looted Millions,"” Mail and Guardian Online, 14 June 2012, http://mg.co.za/ article/2012-06-14-leading-mk-vets-looted-millions.

77 Ngculu, Honour to Serve; and M. Nell and J. Shapiro, No Place by the Fire: The Story of South African Ex-Combatants and the National Peace Accord Trust, 2012, http://www. atlanticphilanthropiesorg/sites/default/files/uploads/ NoPlacebytheFire.pdf; Jacklyn Cock, "The Social Integration of Demobilised Soldiers in Contemporary South Africa," South African Defence Review 12 (1993): 1-16; and Majondina, "Dealing with Difficulties."

78 Ngculu, Honour to Serve, 206-7.

79 Ibid.

80 Nell and Shapiro, No Place by the Fire.

81 Majondina, "Dealing with Difficulties," 223.

82 Ibid.

83 Cock, "Social Integration of Demobilised Soldiers."

84 Nell and Shapiro, No Place by the Fire.

85 Christopher S. Wren, "Uneasily, South Africa Exiles Return," New York Times, 12 March 1991.

86 Arianna Lissoni and Maria Suriano, "Married to the ANC: Tanzanian Women's Entanglement in South Africa's Liberation Struggle," Journal of Southern African Studies 40, no. 1 (2014): 129-50.

87 N. Manghezi, The Maputo Connection (Johannesburg: Jacana Media, 1991).

88 Lauretta Ngcobo, Prodigal Daughters (Durban: University of KwaZulu-Natal Press, 2012).

89 Ibid., 91.

90 Ibid., 44

91 Ibid., 46.

92 Office of the Presidency, National Youth Policy 2009-2014 (Pretoria, 2009), 6, http://www.thepresidency.gov.za/ MediaLib/Downloads/Home/Publications/YouthPublications/NationalYouthPolicyPDF/NYP.pdf.

93 Philippe Denis and Radikobo Ntsimane, Oral History in a Wounded Country: Interactive interviewing in South Africa (Pietermaritzburg: University of KwaZulu Natal Press, 2008).

94 Ibid.
95 Ghosh, "Coda," 284.

96 Nuttall, “Telling 'Free' Stories”; and Gary Minkley and Ciraj Rassool, "Orality, Memory, and Social History in South Africa," in Nuttall and Coetzee, Negotiating the Past, 90-8.

97 Njabulo Ndebele, "Memory, Metaphor and the Triumph of Narrative," in Nuttall and Coetzee, Negotiating the Past, 20.

98 Ingrid de Kok, "Cracked Heirlooms: Memory on Exhibition," in Nuttall and Coetzee, Negotiating the Past, 61.

99 Said, Reflections on Exile, 181.

100 Ibid., 177.

101 Interview, female respondent, Johannesburg, 3 June 2013.

102 Interview, female respondent, Johannesburg, 3 August 2013.

103 Ibid.

104 Zosa O. De Sas Kropiwnicki, "Childhood in Exile: The agency of Second-Generation Exiles Seeking Refuge from Apartheid," Refuge 30, no. 1 (2014): 35-46.

105 Black, "Conceptions of "Home,"' 127; and Hirsch, "Past Lives," 420.

106 Interview, female respondent, Johannesburg, 22 May 2013. 107 Interview, male respondent, Johannesburg, 17 May 2013.

108 Interview, male respondent, Johannesburg, 21 January 2014.

109 Interview, male respondent, Johannesburg, 4 September 2013.

110 Interview, female respondent, Johannesburg, 3 June 2013.

111 Bender and Winer, Contested Landscapes, 9.

112 Interview, male respondent, Johannesburg, 17 May 2013.

113 Interview, female respondent, Johannesburg, 3 August 2013.

114 Muggeridge and Dona, "Back Home?," 427.

115 Interview, female respondent, Johannesburg, 30 May 2013.

116 Interview, female respondent, Johannesburg, 22 May 2013.

117 Interview, female respondent, Johannesburg, 30 May 2013.

118 Interview, male respondent, Johannesburg, 21 January 2014.

119 Interview, female respondent, Johannesburg, 3 June 2013.

120 Interview, female respondent, Johannesburg, 31 August 2013.

121 Interview, male respondent, Johannesburg, 28 May 2013.

122 Interview, female respondent, Johannesburg, 23 May 2013. 123 Ibid.

124 Interview, female respondent, Johannesburg, 6 June 2013.

125 Ibid.

126 Interview, male respondent, Johannesburg, 17 May 2014.

127 Interview, female respondent, Johannesburg, 30 May 2013.

128 Interview, male respondent, Johannesburg, 28 May 2013.

129 Interview, female respondent, Johannesburg, 23 May 2013.

130 Interview, female respondent, Johannesburg, 23 November 2013.

131 Interview, female respondent, Johannesburg, 3 August 2013.

132 Interview, male respondent, Johannesburg, 4 September 2013. 
133 Interview, female respondent, Johannesburg, 3 August 2013.

134 Interview, female respondent, Johannesburg, 23 May 2013. 135 Interview, female respondent, Johannesburg, 6 June 2013. 136 Ibid.

137 Ibid.

138 Interview, male respondent, Johannesburg, 4 September 2013.

139 Interview, female respondent, Johannesburg, 23 November 2013.

140 Interview, female respondent, Johannesburg, 6 June 2013.

141 Interview, female respondent, Johannesburg, 23 November 2013.

142 Ibid.

143 Bender and Winer, "Contested Landscapes," 5.

144 Interview, male respondent, Johannesburg, 17 May 2014.

145 Interview, female respondent, Johannesburg, 23 November 2013.

146 Ibid.

147 Interview, female respondent, Johannesburg, 6 June 2013.

148 Interview, female respondent, Grahamstown, 4 June 2013.

149 Interview, female respondent, Johannesburg, 23 June 2013.

150 Interview, female respondent, Johannesburg, 3 June 2013.

151 Interview, female respondent, Johannesburg, 3 August 2013.

152 Interview, male respondent, Johannesburg, 28 May 2013.

153 Interview, female respondent, Grahamstown, 4 June 2013.

154 Interview, male respondent, Johannesburg, 21 January 2014.

155 Interview, female respondent, Johannesburg, 3 August 2013.

156 Interview, male respondent, Johannesburg, 24 May 2013.

157 Interview, female respondent, Johannesburg, 24 May 2013.

158 Interview, female respondent, Johannesburg, 6 June 2013.

159 Interview, female respondent, Johannesburg, 6 June 2013.

160 Interview, female respondent, Johannesburg, 23 May 2013.

161 Interview, female respondent, Johannesburg, 23 November 2013.

162 Interview, female respondent, Johannesburg, 5 June 2013.
163 Interview, female respondent, Johannesburg, 22 May 2013. 164 Interview, female respondent, Johannesburg, 17 August 2013.

165 Said, "Reflections on Exile," 186.

166 Ibid.; and Hilda Bernstein, The Rift: The Exile Experience of South Africans (London: Jonathan Cape, 1994).

167 Interview, female respondent, Johannesburg, 3 August 2013.

168 Ibid.

169 Interview, female respondent, Johannesburg, 17 August 2013.

170 James Clifford, "Partial Truths," in Writing Culture: The Poetics and Politics of Ethnography, ed. J. Clifford and G. E. Marcus, 91-6 (Berkeley: University of California Press, 1986).

171 Interview, female respondent, Johannesburg, 3 August 2013.

172 Parker, "Home Is Where the Heart ... Lies," 67.

173 Said, "Reflections on Exile," 173-83.

174 See for example AFP, "Namibia Struggle Child Shot Dead," News24, 27 August 2014, http://www.news24.com/Africa/ News/Namibia-struggle-child-shot-dead-20140827.

175 The Presidency, National Youth Policy 2009-2014 (Pretoria: Government Printer, 2009), 33-5, http://www.thepresidency.gov.za/MediaLib/Downloads/Home/Publications/ YouthPublications/NationalYouthPolicyPDF/NYP.pdf.

176 Ibid., 35-6.

177 Ibid., 29-33.

178 Ibid.

Zosa Olenka De Sas Kropiwnicki (Gruber) is a senior lecturer in the Department of Anthropology and Development Studies at the University of Johannesburg. The research was funded by the National Research Foundation Thuthuka Grant (Rating Track). Special acknowledgment must be given to Annette Bayne and Rosalind Elphick, for their invaluable research assistance. The author may be contacted at zosag@uj.ac.za.

(C) Zosa Olenka De Sas Kropiwnicki, 2014. This open-access work is licensed under a Creative Commons Attribution-NonCommercial 4.0 International License, which permits use, reproduction and distribution in any medium for non-commercial purposes, provided the original author(s) are credited and the original publication in Refuge: Canada's Journal on Refugees is cited. 